\title{
Where's the Working Class?
}

\author{
Peter Goodwin
}

\author{
University of Westminster, Communication and Media Research Institute (CAMRI), \\ UK, Germany, goodwip@wmin.ac.uk
}

\begin{abstract}
From the Communist Manifesto onwards, the self-emancipation of the working class was central to Marx's thought. And so it was for subsequent generations of Marxists including the later Engels, the pre-WW1 Kautsky, Lenin, Luxemburg, Trotsky and Gramsci. But in much contemporary Marxist theory the active role of the working class seems at the least marginal and at the most completely written off. This article traces the perceived role of the working class in Marxist theory, from Marx and Engels, through the Second and Third Internationals, Stalinism and Maoism, through to the present day. It situates this in political developments changes in the nature of the working class over the last 200 years. It concludes by suggesting a number of questions about Marxism and the contemporary working class that anyone claiming to be a Marxist today needs to answer.
\end{abstract}

Keywords: Marxism, proletariat, working class, self-emancipation

\section{Introduction}

None of the authors in this Marx bicentenary issue believe that Marxism will be two hundred years old on May 5, 2018. Newly born babies, even ones who would turn out to be as sharp as Karl Marx, do not have such world views ready-made in their heads. It took more than two and a half decades for Marx to become a Marxist and for Marxism itself to be born. As to exactly when that was - and why - there would be a range of differing opinions. When Marx first immersed himself in political economy and articulated his theory of alienation in the 1844 Manuscripts? After an epistemological break with his early Hegelianism whose scientific maturity was first fully displayed in Capital or indeed the Critique of the Gotha Programme? Or, at the extreme, was Marxism as a systematic doctrine a creation of Engels after Marx's death?

This article takes the (probably majority) view that Marxism was born in the mid1840s and (perhaps more controversially) that the birth was the development by Marx (and Engels) of their theory of revolution as the self-emancipation of the working-class. This article follows that thread through the history of Marxism, and concludes by suggesting some of the questions it poses for those of us who might want to claim to be Marxists today.

\section{Marx, Engels and the Self-Emancipation of the Working Class}

The working class became a central part of Marx's thinking after his arrival in Paris in late 1843. By 1846 Marx and Engels had developed their fully-fledged theory of the revolutionary self-emancipation of the working class. The process is outlined in some detail in Löwy (2005) and Draper (1977a; 1977b). Both authors emphasise the impact on Marx's thinking of his direct or indirect encounters with working class communists and working class struggle - the move from comparatively backward Cologne to the great metropolis of Paris; the direct experience of working class communist secret societies in Paris from the Spring of 1844 (Löwy 2005, 50); Engels' experience of English 
workers (and English and Scottish political economy) as published alongside Marx in the Deutsch-Französische Jahrbücher of 1844; the Silesian weavers revolt in June 1844; and finally Marx's first trip to Britain, under the auspices of Engels, in July 1845 and his meetings there with left Chartists.

In his Introduction to a Contribution to a Critique of Hegel's Philosophy of Law, written in late 1843 and January 1844 shortly after his arrival in Paris, Marx, for the first time explicitly envisaged the working class as the agent, or at least instrument, of revolution - although still very much in the language of (however critical) Young Hegelianism. The proletariat was the new universal class, "a sphere which cannot emancipate itself without emancipating itself from all other spheres of society, which, in a word, is the complete loss of man and hence can win itself only through the complete rewinning of man. This dissolution of society as a particular estate is the proletariaf" (Marx 1844a, 186). He concludes: "The head of this emancipation is philosophy, its heart is the proletariat" (Ibid., 187). This still has a distinctly elitist tinge to it. For philosophy read (radical Young Hegelian) philosophers, and, on the worst interpretation the proletariat could simply be seen as cannon-fodder for the intellectuals. But in a polemic with Arnold Ruge over the Silesian Weavers revolt, published in August 1844, Marx makes clear, again for the first time, that the proletariat itself can make its own communist philosophy: "not one of the French or English uprisings had such a theoretical and conscious character as the uprising of the Silesian weavers [...] recall the song of the weavers, that bold call to struggle, in which there is not even a mention of hearth and home, factory and district, but in which the proletariat at once, in a striking sharp and unrestrained manner, proclaims its opposition to the society of private property." (Marx 1844b, 201).

A few months later, in the Holy Family (written in late 1844, published in 1845) Marx makes clear that his concept of the revolutionary role of the proletariat is not one of glorification but of objective assessment.

"When socialist writers ascribe this world-historic role to the proletariat, it is not at all [...] because they regard the proletarians as gods. Rather to the contrary [...] It is not a question of what this or that proletarian, or even the whole proletariat, at the moment regards as its aim. It is a question of what the proletariat is, and what, in accordance with this being it will historically be compelled to do [...] A large part of the English and French proletariat is already conscious of its historic task and is working to develop that consciousness into complete clarity". (Marx and Engels 1845, 36-37)

The theory takes a final step to seeing communist consciousness developing in the proletariat itself in The German Ideology (Marx and Engels 1845/46; Löwy 109-116) and culminates in some of the well-known ringing phrases of The Manifesto of the Communist Party (Marx and Engels 1848). It should not be supposed that these formulations about the self-emancipation of the proletariat are simply a product of Marx's youth. As Michael Löwy observes:

"The theory of revolutionary self-emancipation by the proletariat was not a 'youthful episode,' a transitory moment abandoned by the 'mature' Marx. It remained, for the entire period between 1848 and his death, one of the fundamental assumptions of his political activity. It lights up and helps to endow with their true meaning his great political and politico-ideological battles, the German rev- 
olution of 1848-1850, the fights against Lassalle and Bakunin, the Paris Commune, the critique of opportunism in German Social-Democracy". (Löwy 2005, 149)

\section{The Second and Third Internationals}

For at least forty years after Marx's death this fundamental link between Marxism and the self-emancipation of the working class was taken as a given by virtually everyone who considered themselves a Marxist. It was reasserted on numerous occasions by Engels during the twelve years that he survived Marx.

At least at a verbal level it formed a cornerstone of the leading party of the Second International, the German Social Democratic Party (SPD). Thus the Erfurt Programme of 1891 , by which the party shed its previous compromises with the Lassalleans, asserted that:

"This social transformation [from capitalism to socialism] amounts to the emancipation not only of the proletariat, but of the entire human race, which is suffering from current conditions. But it can only be the work of the working class" (Erfurt Programme 1891).

And, in his lengthy popular gloss on the programme, The Class Struggle written in 1892, the SPD's leading Marxist theoretician, Karl Kautsky devoted much attention to the development and political role of the proletariat (Kautsky 1892, particularly sections II and V).

The volte-face of the SPD into supporting its own government in 1914 raises the question of whether all of this was simply lip-service. But we should note two things in this context. First until 1914 this lip service was accepted at face value by, amongst others, Lenin. Second within the SPD there was a substantial left current (see Schorske 1955) many of whom were later to be founders of the German Communist Party, including Karl Liebknecht, Rosa Luxemburg, Clara Zetkin and Franz Mehring. One can scarcely accuse them of simply paying lip-service to the revolutionary selfemancipation of the working class.

Rosa Luxemburg, in particular, wrote some of the most powerful works of the preWorld War 1 period on the self-activity of the proletariat as a preparation for its revolutionary self-emancipation, most famously Reform and Revolution, written in response to Eduard Bernstein's revisionism, and The Mass Strike, the Political Party and the Trade Unions, commenting on the spontaneous strike waves in the 1905 Russian revolution and their relevance for German Social Democracy (Luxemburg 1900; 1906).

Amid a huge upsurge in working-class self-activity in Europe after the First World War the call of the Bolsheviks to break from the compromised Social Democratic parties, and form new revolutionary Communist Parties in a new revolutionary Communist International met with a huge and enthusiastic response. Here it was clear that the selfemancipation of the proletariat was an essential, very likely the essential, component of Marxism.

Two quotes from the period, one from towards its beginning, one from towards its end, from thinkers who have subsequently been (misleadingly) grouped into the distinctly academically-oriented construct "Western Marxism" (Anderson 1976, 25-26) bear this out. First the Italian Communist, Antonio Gramsci, writing in 1919 in relation to the factory councils of Turin: 
"The socialist State already exists potentially in the institutions of social life characteristic of the exploited working class. To link these institutions, co-ordinating and ordering them into a highly centralized hierarchy of competences and powers, while respecting the necessary autonomy and articulation of each, is to create a genuine workers' democracy here and now - a workers' democracy in effective and active opposition to the bourgeois State, and prepared to replace it here and now" (Gramsci 1919, 65)

Second the Hungarian Communist Georg Lukács writing in 1924 the opening of his little book Lenin:

"Historical materialism is the theory of the proletarian revolution. It is so because its essence is an intellectual synthesis of the social existence which produces and fundamentally determines the proletariat: and because the proletariat struggling for liberation finds its clear self-consciousness in it" (Lukács 1970, 9).

\section{Who Were the Proletariat and What Were They Supposed to Do?}

Given that the proletariat was so central to Marx and Engels' thought from the mid1840s onwards what precisely did they understand by the proletariat? First it should be understood that from the beginning they used "proletariat" and "working class" interchangeably. As Engels put it explicitly in March 1845 in his preface to The Condition of the Working Class in England: "I have continually used the expressions workingmen (Arbeiter) and proletarians, working-class, propertyless class and proletariat as equivalents" (Engels 1845, 304).

This flexibility of usage persisted in the work of both Engels and Marx, and of subsequent Marxists. But alongside that early flexibility, there was a clear conception of who that proletariat/working class was. Engels makes the point explicitly - this time in his Principles of Communism, a catechism-like presentation of many of the ideas soon to be incorporated in the Communist Manifesto:

\section{"Question 2: What is the proletariat?}

Answer: The proletariat is that class of society which procures its means of livelihood entirely and solely from the sale of its labour [...] whose whole existence is dependent on the demand for labour, hence [...] on the fluctuations resulting from unbridled competition. The proletariat [...] is, in a word, the working class of the nineteenth century.

\section{Question 3: Then there have not always been proletarians?}

Answer: No. Poor folk and working classes have always existed [...] But such poor, such workers who live under the conditions just stated, that is proletarians, have not always existed, any more than competition has always been free and unbridled" (Engels 1847, 341).

So, for Marx and Engels, the proletariat consisted of those who lived by selling their labour (or rather, as the pair were soon to refine their economic terminology, their labour power) under capitalism. Even this wide definition clearly excludes peasants and other true petty-bourgeois (those who owned their own means of production). In most of their writings, Marx and Engels went further, implicitly narrowing down this broader definition to urban workers and assuming that these were concentrated in factories. So 
excluded from the "core" proletariat were agricultural labourers and the then not at all insignificant category of domestic servants.

Various remarks in Marx's economic writings make further exclusions but also explicitly assert some important (at least to subsequent debates) inclusions. So excluded were wage workers directly employed by government (since, for Marx, they did not produce surplus-value). But explicitly included were service workers (i.e. workers producing non-material goods) and "white collar" workers (Marx gives the example of a teacher in a private school) and workers in distribution (Draper 1977b, 34-35). As Hal Draper observes, these economic qualifications and clarifications, on the one hand separate Marx's view of the proletariat, from the caricature of "dirt splattered, hornyhanded blue collar toilers", but on the other hand they leave one with the apparently perverse result that "an editorial supervisor of the Encyclopedia Britannica may be a proletarian while a Navy Yard shipfitter is not" (Ibid., 35-36). But these are not only "extreme" examples, they were also, in Marx's time fairly uncommon ones.

With the benefit of hindsight, two observations need to be made about these conceptions of the proletariat:

First, on either a broader or a narrower definition the proletariat were a distinct minority in Marx's time in Western Europe and North America, never mind on a world scale. Major "developed" Western European economies (for instance France) retained a majority or near majority agricultural sector, dominated numerically by peasant proprietors, until the Second World War. But the corollary of this is that from the time that Marx "discovered" the proletariat in the mid-1840s, the proletariat on any definition unquestionably continued to grow - in Europe and North America until well into the second half of the twentieth century, and in Asia, most notably and dramatically in China, until the present day.

Second, the niceties that Marx's economic enquiries drew or explicitly didn't draw about the boundaries of the proletariat were not of a great deal of social or political importance until well into the second half of the twentieth century. The proletariat or working class, both objectively and subjectively, were by and large manual, by and large urban, and if they satisfied these two criteria behaved exactly like proletarians even if they were in direct state employment. In hindsight Marx certainly greatly exaggerated the communist consciousness of the Silesian weavers' revolt of 1844 in his contemporaneous polemic, or a writing a few months later similarly exaggerated when he said that "a large part" of the English and French proletariat was already conscious of its historical role. But with equal hindsight we can also say that for over a hundred years after Marx (and Engels) "discovered" the proletariat, proletarians organised and struggled in large numbers, and in very significant numbers numerically dominated mass parties which proclaimed themselves Marxist, like the German SPD before the First World War and the European Communist Parties after it.

\section{Marxism without the Proletariat?}

Given the history we have just described the notion of Marxism without the proletariat seems a strange one. But one of the first schools of thought along these lines flourished for a short while precisely during the period when in the rest of the self-labelled Marxist world the fundamental link between Marxism and the working-class was seen as a truism. This school of thought was Russian "Legal Marxism" of the 1890s whose most notable figure was Peter Struve and who were formally part of the then very loose Russian Social Democratic and Labour Party, as was Lenin. They used Marxism, like Lenin, against the peasant-oriented Narodniks, to argue that capitalism was developing in Russia. But that was all. Unlike Lenin they did not add to this the need for working 
class struggle (Zinoviev 1973, 38-47). In effect "Legal Marxism" was an ideology of the developing Russian capitalist class, a verdict confirmed by the very rapid movement of Struve and its other leading figures into being founders of the openly-capitalist Cadet Party soon after the end of their "Marxist" period.

Russian Legal Marxism was of course a very specific product of a very specific time in the history of a very specific country. It would be unwise to generalise very much from it. But what it does illustrate is that it is perfectly possible for self-described "Marxists" to eliminate the proletariat from their "Marxism", and in doing so to produce not only something quite different from what Marx, Engels or their successors would have recognised, but also something that hitches "Marxism" to the interests of a quite different class.

Since the early years of the Communist International and the ending of the years of revolutionary upsurge in Europe that followed the First World War, we can identify two wide-ranging tendencies which have laid the ground for various types of self-styled "Marxism" without the self-emancipation of the working class. The first is most obviously political but with deep (and various) social roots, the second most obviously social but with numerous and varied political implications. The first is the rise and dominance of what, for want of a less contentious word, I shall call Stalinism. The second is the ups and downs in class struggle and changes in social structure over the last hundred years. I will deal with each in a very short and simplified way, from the point of view of what consequences they might have for the relation between self-styled Marxism and the self-emancipation of the working class.

First, Stalinism. From late 1923, on the back of the defeat of the revolutionary wave in Western and Central Europe, the consequent isolation of the Russian Revolution, and the social and political disintegration of the Russian working class which had made the October Revolution, the bureaucracy in Russia represented by Stalin advanced its position. By 1928 with the first five-year plan, the turn against the peasants, the final liquidation of any sort of inner-party dissent and crash industrialisation, Stalin and the bureaucracy that he represented consolidated themselves into a national ruling class (Harman 1967).

This had profound consequences on the international stage:

"In the period 1924-28 the Comintern became a 'centrist' body - Trotsky coined the term 'bureaucratic centrism' to describe its policies - though it still carried, with increasing distortions and degeneration, something of the tradition of its revolutionary years. After 1928 the last elements of these were progressively liquidated, just as the last elements of workers' power in the USSR were liquidated" (Hallas 1985, 165).

"Marxism" for most people became whatever the Russian Stalinist bureaucracy proclaimed it was. From 1928 to 1934 that was a mechanical and disastrous ultra-left turn (to coincide with "collectivisation" of agriculture and crash industrialisation). From 1934 it was the distinctly right-wing turn of the Popular Front. With the exceptions of the Nazi-Soviet pact of 1939-41, and their exit from the post-war coalition governments in Western Europe in 1947/48, popular frontism persisted in the orientation of the Communist parties right through to the demise of the Soviet Union.

In the years following the Second World War, Stalinism could present itself as a considerable success story, not merely in the USSR, but also outside. New regimes identical to Stalin's USSR - the "People's Democracies" - were created by the Red 
Army in Eastern Europe. Elsewhere, in China and North Vietnam similar regimes were established by Communist Party-led peasant armies.

From the perspective of Marxism as revolutionary self-emancipation the consequences of these developments were three-fold.

First, for most self-described Marxists either within the Stalinist countries or in the Stalinised Communist Parties outside them, Marxism became a somewhat lifeless doctrine, where quotes from the masters, were regularly employed to defend the vested interests and latest policy turns of a national bureaucratic ruling class. Even for many "independent" Marxists, employing Marxist methods in academic disciplines like economics or history, this meant that the self-emancipation of the working class took a back seat.

Second, decades of popular frontism, coupled with the victories of distinctly nonworking class revolutions in China and elsewhere, meant that the concept of the working class, as a class with distinct characteristics, could seem rather less central to the political practice of Marxism, than the vaguer, wider and (often opportunistically) more flexible category of "the people".

Thirdly, if emancipation can be brought about by either Stalin's Red Army or Mao's People's Liberation Army, without any obvious activity by the working-class then what becomes of working-class self-emancipation?

Alongside the political phenomenon of Stalinism, have been the social phenomena of the ups and downs of class struggle and changes in class structure. Again, I will be very simplified and schematic.

From Marx and Engels onwards, Marxists have never claimed that the workingclass as a whole always has a revolutionary, or indeed a socialist, class consciousness. On the one hand, as some of the quotations I have already cited indicate, even at their most optimistic (e.g. Marx and Engels 1845, 36-37) Marx and Engels proposed that this was a tendency rooted in the nature of the proletariat. Marx, Engels and their successors also readily recognised that there are ebbs and flows in the class struggle, which along with various political, economic and social factors, can inhibit or encourage class consciousness. Among the factors identified by Marx and later Marxists as affecting levels of class struggle and socialist consciousness have been the state of the economy, the influence of reformist political or trade union organisation, labour bureaucracy and aristocracy, nationalism, conscious stratagems by the ruling class, influence of the petty bourgeoisie, etc. And one of the claims for Marxist political organisation from The Manifesto of the Communist Party onwards, was that it was through a revolutionary party that the most aware of the proletariat, could conduct propaganda and agitation to maximise the effect of class struggle in bringing to socialist consciousness the mass of their fellows. This, of course, entailed often highly detailed and highly specific discussion of tactics and organisation. That is what many of the most famous works of "classical" Marxism (e.g. Lenin (1902) and Luxemburg (1906)) are all about.

One important set of factors which Marxists from Marx onwards identified as holding back the development of revolutionary or socialist consciousness by the working class is the existence of various real social divisions among wage earners - foremen and those they manage, skilled and unskilled, blue and white collar etc. It is out of some of these divisions that the concept of the "aristocracy of labour" developed although it should be noted here that skilled craft workers have played an important part in the labour movement and in its revolutionary side from the start, including in the early Communist Parties.

To hugely simplify, we can note that these social divisions among wage workers were perceived among Marxists as having very little impact on the centrality of the 
working class to their theory until after the Second World War. White collar workers were growing, but so too were "classic" blue collar (with the continued move from countryside to city in Europe and America). And, with ups and downs in class struggle (and among the ups was the huge one following the First World War during which the Communist International was established) for more than 90 years after Marx's death blue collar workers in Europe and America continued to build and grow trade union organisations, and in the latter of those years were joined in that effort by large numbers of white collar or professional workers.

However, in the boom decades of the 50s and 60s growing affluence appeared to many commentators to be accompanied by diminished class consciousness - supposedly particularly evidenced in the declining vote for and decline in participation in working class (generally social democratic) parties. Such views, sometimes summed up under the heading of the "embourgeoisement" thesis, were advanced, with varied degrees of nuance, generally by observers from the right of social democracy. But they, and the facts to which they alluded, had an impact on many Marxist intellectuals. One of the most notable examples is Paul Baran and Paul Sweezy's widely read Monopoly Capital: An Essay on the American Economic and Social Order, first published in 1966. Having analysed and critiqued that order, Baran and Sweezy, turned to what might bring it to an end:

\begin{abstract}
"The answer of traditional Marxist orthodoxy - that the industrial proletariat must eventually rise in revolution against its capitalist oppressors - no longer carries conviction. Industrial workers are a diminishing minority of the American working class, and their organized cores in the basic industries have to a large extent been integrated into the system as consumers and ideologically conditioned members of the society". (Baran and Sweezy 1968, 349)
\end{abstract}

Instead, Baran and Sweezy saw the likely threats to American monopoly capitalism being the wars waged by "revolutionary peoples [which] have achieved historic victories in Vietnam, China, Korea, Cuba and Algeria" and the "socialist countries show[ing] by their example that it is possible to use man's mastery over the forces of nature to build a rational society satisfying the human needs of human beings" (Baran and Sweezy 1968, 351; 352).

Monopoly Capital exemplifies two types of "Marxism without the working class" which were a product of a perceived prolonged downturn in domestic class struggle. The first is Marxism as pure critique (in this case mainly economic) of capitalism. The second type, in the conclusion just cited, sees an agency of change but not a working class one - instead we have the "revolutionary wars" of the oppressed peoples or peasants of what was then termed the underdeveloped world. Both types were very much products of their time and the latter was to be taken up with considerable vigour in the following decade by various strands of Maoists in America, Western Europe and elsewhere.

The conventional post-war wisdom of the passivity of the working class was shattered by the huge upturn in industrial and political militancy, particularly in Western Europe, in the late 1960s and early 1970s, whose high points included the French May Events of 1968, and the Italian Hot Autumn of 1969. This upturn featured militancy by the classic industrial working class - for instance the carworkers, who had been both the subject of Gramsci's attention in 1919, and the attention of the sociologists of "embourgeoisement" in the 1960s. It also featured extensive militancy by white collar and 
professional wage-earners, who during this period joined unions and took part in industrial action in historically unprecedented numbers. Were these too part of the working class, making up for the decline in blue collar and manufacturing employment? Marxists at the time pondered the question (see Wright 1978, 30) and some (for instance Callinicos and Harman (1987)) readily concluded that most white-collar and professional wage-earners were part of the proletariat.

The four decades since the upsurge of working class militancy in the late sixties and early seventies have seen further enormous changes in both occupational and class structure and politics. Very schematically, we can list some of the most notable of these:

- The decline in manufacturing and blue-collar employment in the "advanced" economies of Europe and North America has continued.

- Unionisation in these economies has steadily declined from its highpoint in the late 1970s.

- White collar wage earners have continued to expand in numbers (now considerably outnumbering blue collar in these economies), but with some very different patterns of employment - for example the decline of some big routine white-collar workplaces and the rise of new occupations linked with information technology.

- Alongside these developments in Europe and North America, has gone a massive expansion of the numbers of wage earners, including a massive expansion of blue collar and manufacturing wage earners, in much of the rest of the world. On at least one measure there can never have been more proletarians on the earth than there are now. But it may also be the case that they have rarely been less organised.

- These four decades have also been the decades of the dominance of neo-liberalism - and there is clear connection between that and some of the trends I have just noted. The ideological dominance of neo-liberalism has been shaken by the crash of 2008 and its austerity aftermath. That in turn has produced a growth in the intellectual attractions of Marxism and also a "populist" revolt by many of those who now realise how much they have been short-changed by neo-liberalism's "achievements". However, to date, much of that "populist" revolt has taken a distinctly rightwing form and those right-wing politics have seemed particularly attractive among sections of the "classic" industrial blue-collar workers.

\section{Questions for Today's Marxists}

A rise in intellectual attraction of Marxism as critique of a failed system alongside the rise of right-wing politics with an apparently proletarian base - that seems a recipe for "Marxism without the working class".

In these circumstances there are a number of questions which those of us who might want to consider ourselves Marxists need to address:

First, and most fundamental: Is it possible to be a Marxist without accepting the self-emancipation of the working class as an integral part of Marxism? For those who want to reply "Yes" two further questions follow:

(a) How does this make Marxism different from any other critique? In other words whatever happened to "the point is to change it"?

(b) Or is there perhaps some other agency of change - perhaps a reconstituted "people" for the 21st century? If so we need to know the details. 
For those whose reply to our fundamental question is a firm "No" three further questions follow:

(a) Is the proletariat still centred around blue collar workers and/or manufacturing but has the weight of these now decisively relocated from its previous bases in Europe and North America?

(b) Is the proletariat, on the other hand, equally centred among the new white collar occupations, particularly those associated with information technology? And if so are the tools developed by Marxists in the seventies to analyse these groups still adequate? If not what are the new ones?

(c) And finally - whether we choose positive answers to (a) and/or (b) - what leads us to believe that this $21^{\text {st }}$ century proletariat will act as a class seeking its self-emancipation?

These are not easy questions and they don't have easy answers. But any of us who wants to be called a Marxist two hundred years after Marx's birth needs to ask them, and make a serious start on giving answers.

\section{References}

Anderson, Perry. 1976. Considerations on Western Marxism. London: NLB.

Baran, Paul A. and Sweezy, Paul M. 1968. Monopoly Capital: An Essay on the American Economic and Social Order. Harmondsworth: Penguin Books.

Callinicos, Alex and Chris Harman. 1987. The Changing Working Class. London: Bookmarks.

Draper, Hal. 1977a. Karl Marx's Theory of Revolution: Volume 1: State and Bureaucracy. New York: Monthly Review Press.

Draper, Hal. 1977b. Karl Marx's Theory of Revolution: Volume 2: The Politics of Social Classes. New York and London: Monthly Review Press.

Engels, Frederick. 1847. Principles of Communism. In MECW Volume 6, 341-357. London: Lawrence \& Wishart.

Engels, Frederick. 1845. The Condition of the Working-Class in England. In MECW Volume 4, 295-583. London: Lawrence \& Wishart.

Erfurt Programme. 1891. The Erfurt Programme. Translated by Thomas Dunlap. Accessed 24 January 2018. https://www.marxists.org/history/international/social-democracy/1891/erfurt-program.htm

Gramsci, Antonio. 1919. Workers Democracy. Ordine Nuovo, 21 June 1919. In Antonio Gramsci: Selections from the Political Writings 1910 -1920, 65-68. London: Lawrence and Wishart.

Hallas, Duncan. 1985. The Comintern. London: Bookmarks.

Harman, Chris. 1967. Russia: How the Revolution was Lost. International Socialism (1st series) 30: 8-17.

Kautsky, Karl. 1892. The Class Struggle. New York: WW Norton \& Co.

Lenin, Vladimir Ilyich. 1902. What is to be Done? Collected Works Volume 5, 347-530. Moscow: Foreign Languages Publishing House.

Löwy, Michael. 2005. The Theory of Revolution in the Young Marx. Chicago, IL: Haymarket Books.

Lukács, Georg. 1970. Lenin: A Study in the Unity of his Thought. London: NLB.

Luxemburg, Rosa. 1906. The Mass Strike, the Political Party and the Trade Unions. In Rosa Luxemburg Speaks, edited by Mary-Alice Waters, 33-90. New York: Pathfinder Press.

Luxemburg, Rosa. 1900. Reform or Revolution. In Rosa Luxemburg Speaks, 153-218, edited by Mary-Alice Waters, 153-218. New York: Pathfinder Press. 
Marx, Karl. 1844a. Introduction to Contribution to the Critique of Hegel's Philosophy of Law. In MECW Volume 3, 175-187. London: Lawrence \& Wishart.

Marx, Karl. 1844b. Critical Marginal Notes on the Article "The King of Prussia and Social Reform. By a Prussian". In MECW Volume 3, 189-206. London: Lawrence \& Wishart.

Marx, Karl and Frederick Engels. 1848. Manifesto of the Communist Party. In MECW Volume 6, 477-519. London: Lawrence \& Wishart.

Marx, Karl and Frederick Engels. 1845/46. The German Ideology. In MECW Volume 5, 19539. London: Lawrence \& Wishart.

Marx, Karl and Frederick Engels. 1845. The Holy Family. In MECW Volume 4, 5-211. London: Lawrence \& Wishart.

Schorske, Carl E. 1955. German Social Democracy 1905-1917: The Development of the Great Schism. Cambridge, MA and London: Harvard University Press.

Wright, Erik Olin. 1978. Class, Crisis and the State. London: NLB.

Zinoviev, Grigorii. 1973. History of the Bolshevik Party - A Popular Outline. London: New Park Publications.

\section{About the Author}

\section{Peter Goodwin}

Peter Goodwin is a Principal Research Fellow in CAMRI, the Communication and Media Research Institute, at the University of Westminster, UK. He has published on media policy, public service media and the political economy of communication. 